\title{
Influence of feeding regimen on growth parameters of African Catfish (Clarias gariepinus, Burchell 1822)
}

\author{
${ }^{1}$ Abanikannda, O. T. F., ${ }^{2}$ Jimoh, A. A., ${ }^{1}$ Bakare, K. O., ${ }^{1}$ Shitta, S. A. and ${ }^{1}$ Shopeyin, Z. F.
} ${ }^{\prime}$ Department of Zoology and Environmental Biology, Lagos State University, Ojo - Lagos,

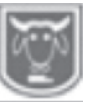

Nigeria

${ }^{2}$ Department of Fisheries, Lagos State University, Ojo - Lagos, Nigeria

Corresponding author: otfabanikannda@hotmail.com; +234 8023128376

\begin{abstract}
An experiment was conducted using 270 African catfish fingerlings to evaluate the effects of different feeding regimen on growth performance of the fish. The fish were hatched and reared to 12 weeks under similar condition before the commencement of the experiment that lasted for 40 days. Feeding regimens included equally shared feed based on recommended of $5 \%$ body weight, and equally spaced feed allocation at 6, 8 and 12 hourly intervals. Each of the three treatment groups comprised of six replicates of 15 fish per plastic tank. Body weight, and two linear measurements (total and standard length) were taken twice weekly on each of the fish in all the tanks and the respective length-weight relationship and condition factor $(K)$ were computed. Weekly gain, final weight, average daily gain, absolute, relative, specific and mean growth rates for the three groups were evaluated and compared. Results showed that all parameters studied except final total length were significantly $(P<.05)$ affected by feeding regimen. The coefficient of determination for all ANOVA had variable values for all growth parameter; Final Weight (83.11\%), Absolute Growth Rate (79.19\%), Final Total Length (61.30\%), Final Standard Length (60.87\%), Relative Growth Rate (38.68\%), Specific Growth Rate (35.57\%), Mean Growth Rate (32.23\%) and Condition Factor (12.83\%). The 6hourly treatment group mostly had the highest values across all the parameters studied but was not statistically different $(P>.05)$ from the values obtained in the 8-hourly group.
\end{abstract}

Keywords: Growth parameters, feeding regimen, fish rearing, Aquaculture

\section{Introduction}

African catfish (Clarias gariepinus) is becoming increasingly popular in Africa as a result of its wide acceptability across ethnic, cultural and religious divides. It is a veritable source of animal protein. Its relative ease of culturing in artificial tanks, hardiness and omnivorous attributes makes it a preferred specie in aquaculture (Adebayo and Fagbenro, 2004). As at 2010, Nigeria accounted for 62.65 percent of the total production of clariid catfish in Africa (FAO, 2012) and artificial culture of the species has since been on the increase. Clarias gariepinus is ideal for culture because of its tolerance to low dissolved oxygen, rapid growth rate, acceptability of varieties of feed resources and ability to withstand stress associated with its handling. Market demand for catfish also continues to increase over years for its delicious taste and relatively affordable price (Zidni et al., 2013; Hecht, 2013). Four major production challenges have been identified to confront profitable and sustainable aquaculture (George et al., 2010), and feeding remains the biggest threat to fish rearing, with regards to the quality and quantity of feed on one part and its availability and affordability on the other part. It has been reported that feed represents $40-50 \%$ of production cost, and fish nutrition has advanced dramatically in recent years with the development of new, balanced commercial diets that promote optimal fish growth and health (Craig, 


\section{Influence of feeding regimen}

2002). Thus, to improve on the culture of Clarias gariepinus, there is need to produce quality table size fish within the shortest possible time and at minimum cost to ensure optimal return on investment (Booth et al., 2008 and Ndome et al., 2011). Aquaculturists typically report growth using absolute $(\mathrm{g} / \mathrm{d})$, relative $(\%$ increase in body weight), and specific growth rates $(\% \mathrm{~d})$ and each of these rates is a numerical representation of growth which assumes a specific relationship between size and time (Hopkins, 1992). Fish growth is influenced by feed availability and intake, genetics, age and size, environment and nutrition, and feed intake is perhaps the most prominent factor affecting growth rate of fish (Li et al., 2004). In a bid to overcome the inadequacy of feeding, there is the need to strike a balance between rapid fish growth and optimum use of supplied feed by recommending the optimal feeding frequency to reduce wastage and its attendant economic losses. Such problems can be solved by avoiding the twin traps of overfeeding and underfeeding, which are both detrimental to the health of the fish and may cause marked deterioration in water quality, reduced weight, poor food utilization, and increased susceptibility to infections (Priestley et al., 2006). It may also affect the specific growth rates and the efficiency of feed conversion as these have been observed to be directly related to feed ration and frequency. When fish are fed at optimal feeding frequency, growth and survival rates are expected to improve because this regulate their feed intake in relation to their energy demand (Schnaittacher et al., 2005), and times of feeding and feeding frequency have been reported to affect feed intake and growth performance in fishes (Ali et. al. 2005). This study aims to investigate the growth performance of Clarias gariepinus fed at three different equal intervals of 6,8 and 12 hours per day as expressed by their weekly gain, mean, absolute, relative and specific growth rates. Thus, the objective of this study was to make comparative analysis of the weekly growth rate and other growth parameters under the three differing feeding regimes, and recommend the optimal feeding frequency for the African catfish rearing.

\section{Materials and methods The study site}

The study was entirely conducted at the Lagos State University, along Badagry Expressway, Ojo, Lagos State at latitude $6^{\circ}$ $28.226^{\prime} \mathrm{N}$ and longitude $3^{\circ} 12.019^{\prime} \mathrm{E}$, with an average annual rainfall of $1693 \mathrm{~mm}$ and average temperature of $27.0^{\circ} \mathrm{C}$. The first part of the experiment was set up at the Hatchery of the Department of Fisheries, while subsequent rearing was at the Department of Zoology laboratory. The Hatchery has an indoor flow through system with several concrete tanks and the fry were raised in plastic tanks of equal size and dimensions.

\section{Experimental unit}

Four brood stocks comprised of three females and one male, with each female weighing $645 \mathrm{~g}, 525 \mathrm{~g}$ and $525 \mathrm{~g}$, respectively while the male weighed $2,325 \mathrm{~g}$, were procured from a reputable commercial fish farm along Badagry Expressway, Lagos State, Nigeria. The fish were separated by sex and left for some time to acclimatize, before the females were induced with artificial hormone (Ovaprim). Egg striping was done 8 hours after by gently pressed the abdomen with a thumb started from the area of the chest, moved towards the genital papillae into a clean bowl. The male was sacrificed with its testes removed and kept in a clean bowl. Milt was collected by maceration of the testes and mixed saline solution. Thereafter, the milt was added to the egg 


\section{Abanikannda, Jimoh, Bakare, Shitta and Shopeyin}

and mixed by gently shaking the bowl and the fertilized eggs were spread on wire mesh inside the breeding tank. After about 22 hours, hatchlings were noticed swimming around the mesh net, carrying their yolk, the mesh was removed a day after hatching, and dead eggs were siphoned out. Feeding commenced on the third day after absorption of yolk and frys were fed with artemia for three weeks, before introduction of Coppens commercial fish feed of varied sizes depending on the stage of development as described by Abanikannda et al (2019). The fingerlings were kept and reared under same conditions for 12 weeks when the fingerlings were strong enough to withstand the rigors of handling during measurements.

\section{Experimental design}

Two hundred and seventy 12-week old fingerlings weighing between $5.00 \mathrm{~g}$ $14.96 \mathrm{~g}$ were randomly selected and randomly assigned to three different and independent treatment groups $(6,8$ and 12 hourly regimen), each with 90 fingerlings per treatment. The fingerlings were fed at the recommended 5 percent of their body weight and the feed was apportioned into 4, 3 or 2 parts daily for each feeding regimen. There were six replicates per treatment with each plastic tank, measured $30 \mathrm{~cm} \mathrm{x} 48 \mathrm{~cm} \mathrm{x}$ $29 \mathrm{~cm}$ each holding 15 fingerlings. A preliminary statistical analysis of the mean weights across all the 18 tanks at the commencement of the experiment was fairly uniform and not different $(\mathrm{P}>0.05)$.

Fingerlings assigned to treatment $\mathrm{A}$ were fed four times daily at 6 hourly intervals at $12 \mathrm{am}, 6 \mathrm{am}, 12 \mathrm{pm}$ and $6 \mathrm{pm}$ while treatment B were fed three times daily at 8 hourly intervals at $12 \mathrm{am}, 8 \mathrm{am}$, and $4 \mathrm{pm}$ respectively, and treatment $\mathrm{C}$ were fed twice daily at 12 hourly intervals at. $12 \mathrm{am}$ and $12 \mathrm{pm}$ daily. Irrespective of the treatment group, the fingerlings were fed daily with $3 \mathrm{~mm}$ Coppens commercial feed at $5 \%$ of their body weight throughout the experimental period, and the tank water was changed every two days to maintain good water quality.

\section{Measurements and data collection}

Individual body weight (g), total length $(\mathrm{cm})$ and standard length $(\mathrm{cm})$, of each fish were taken twice a week using digital balance for the body weight and meter rule for total and standard length and feed offered was measured using digital balance sensitive to $0.00 \mathrm{~g}$. Data collected were transcribed and entered onto Excel Worksheet comprising columns indicating Tank ID, Weight, Total Length and Standard Length at specified intervals.

\section{Data preparation and statistical analyses}

Aside from the weight, total length and standard length recorded at the commencement of the experiment which was defaulted to initial values, further recordings were made at intervals spanning a period of 40 days. Each recording was appropriately tagged and weekly measurements were computed as the difference between the current and prior week recordings. Other parameters such as Absolute Growth Rate (AGR), Specific Growth Rate (SGR), Relative Growth Rate (RGR) and Mean Growth Rate (MGR) were computed by methods of Brown (1957), Ricker (1975), Bagenal (1978), and Varela et al, (2010) as follows:

$$
\begin{aligned}
& A G R=\left(\frac{W_{t}-W_{i}}{t}\right) \\
& S G R(\%)=\left(\operatorname{Ln} \underline{W}_{t}-\frac{\operatorname{Ln} W_{i}}{t}\right) \times 100 \\
& R G R(\%)=\left(\frac{W_{f}-\frac{W_{i}}{W_{i}}}{i}\right) \times 100 \\
& \operatorname{MGR}(g / d a y)=\left(\frac{W_{t}-W_{i}}{0.5\left(W_{f}-W\right) t}\right) \times 100
\end{aligned}
$$




\section{Influence of feeding regimen}

Where $\mathrm{W}_{\mathrm{f}}$ was final weight $(\mathrm{g}), \mathrm{W}_{\mathrm{i}}$ was initial weight (g), t was time (days), and Ln is natural logarithm.

Indices such as length weight relationship and Fulton's condition factors were estimated using the formula of Tesch (1968) and Fulton (1904) as described by Abanikannda et al. (2019) as follows:

$$
W=a L^{b}
$$

which was transformed as $\log W=\log a+$ $b \log L$. The Fulton's Condition Factor was given as;

$$
K=\left(\frac{W .100}{L^{2}}\right)
$$

where $\mathrm{W}=$ Weight in gram, $\mathrm{L}=$ length in (cm), $\mathrm{a}=\mathrm{a}$ constant being the initial growth index, and $b=$ growth coefficient. $\mathrm{K}$ is the condition factor.

Preliminary exploratory analyses were done to check data validity, assess for outlier values and test for normality. The General Linear Models of ANOVA was used to test for differences between treatments for the three measurements studied (weight, total length and standard length) and the computed indices (weekly gain, length-weight relationship, condition factor, absolute, specific, relative and mean growth rates). The statistical model used in the final analyses is given as;

$Y_{\mathrm{ijk}}=\mu+\alpha_{\mathrm{i}}+\beta_{\mathrm{j}}+\mathrm{e}_{\mathrm{ijk}}$

$\mathrm{Y}_{\mathrm{ijk}}=$ Observed measure for each variable

$\mu=$ Overall mean

$\alpha_{i}=$ Effect of feeding regime ( $i=6$ hourly, 8 hourly and 12 hourly)

$\beta_{\mathrm{j}}=$ Initial reading as Covariate

$\mathrm{e}_{\mathrm{ijk}}=$ Residual error

\section{Results}

\section{Measured variables}

The mean \pm SE initial weight at the commencement of the experiment was $7.15 \pm .17 \mathrm{~g}, 7.05 \pm .17 \mathrm{~g}$ and $7.17 \pm .17 \mathrm{~g}$, respectively for the three treatments $(6,8$ and 12 hourly), while the overall mean across the three treatments was $7.13 \pm .10 \mathrm{~g}$. There was no statistical difference $(\mathrm{P}>.05)$ in the initial weight across the three treatments and all were fairly homogenous. The weekly gain in weight across the three treatments is presented in Figure 1. There was difference $(\mathrm{P}<.05)$ amongst treatments in all the weekly weight gain except for the $5^{\text {th }}$ week that was not significant $(\mathrm{P}>.05)$. Also, the 6 hourly regimen mean was consistently superior throughout the study except for the first week, whereby the 8 hourly regimen mean was highest.

The effect of treatment on final weight was highly significant $(\mathrm{P}<.01)$ and the model ascribed 83.1 percent of variation in final weight to the combined effects of initial weight and treatment group (Table 1). The 6-hourly treatment had the highest final weight gain of $32.33 \pm 1.39 \mathrm{~g}$ which was not significantly $(\mathrm{P}>.05)$ different from $30.54 \pm 1.42 \mathrm{~g}$ recorded in the 8-hourly regimen but both values were significantly $(\mathrm{P}<.05)$ higher than the $29.27 \pm 1.34 \mathrm{~g}$ recorded for the 12-hourly regimen.

\section{Total length}

The overall $(n=270)$ mean of initial total length in the study was $12.49 \pm .06 \mathrm{~cm}$ with respective means for the three treatments $(6$, 8 , and 12 hourly) as $12.48 \pm .09 \mathrm{~cm}$, $12.47 \pm .11 \mathrm{~cm}$ and $12.51 \pm .10 \mathrm{~cm}$. There was no statistical difference $(\mathrm{P}>.05)$ in the treatment means all through the study except for second week where the 6-hourly regimen had significantly $(\mathrm{P}<.05)$ higher values than the other two treatments. Weekly gain in total length is presented in Figure 1.

There was no statistical $(\mathrm{P}>.05)$ difference in the final total length recorded in the study (Table 1) which was respectively $9.92 \pm .20 \mathrm{~cm}, 9.41 \pm .22 \mathrm{~cm}$ and $9.57 \pm .21 \mathrm{~cm}$ for the 6,8 and 12-hourly regimen, while the overall mean total length was $9.63 \pm .12 \mathrm{~cm}$. The model accounted for 61.3 percent of variation in final total length across the three treatments. 
Abanikannda, Jimoh, Bakare, Shitta and Shopeyin

Table 1: General Linear Models ANOVA Table of Growth Parameters of Clarias gariepinus

\begin{tabular}{|c|c|c|c|c|c|c|c|c|c|}
\hline Sources of Variation & $\begin{array}{l}\text { Degrees } \\
\text { of } \\
\text { Freedom }\end{array}$ & Final Weight & $\begin{array}{l}\text { Final } \\
\text { Total } \\
\text { Length }\end{array}$ & $\begin{array}{l}\text { Final } \\
\text { Standard } \\
\text { Length }\end{array}$ & $\begin{array}{l}\text { Condition } \\
\text { Factor }\end{array}$ & $\begin{array}{l}\text { Specific } \\
\text { Growth } \\
\text { Rate }\end{array}$ & $\begin{array}{l}\text { Absolute } \\
\text { Growth } \\
\text { Rate }\end{array}$ & $\begin{array}{l}\text { Relative } \\
\text { Growth } \\
\text { Rate }\end{array}$ & $\begin{array}{l}\text { Mean } \\
\text { Growth } \\
\text { Rate }\end{array}$ \\
\hline Initial Weight & 1 & $47278.3^{* * *}$ & $1062.39^{* * *}$ & $902.83^{* * *}$ & $0.24^{* * *}$ & $34.99^{* * *}$ & $25.25^{* * *}$ & $1174283^{* * *}$ & $11.84^{* * *}$ \\
\hline Treatment & 2 & $234.5^{* *}$ & $4.12^{\mathrm{ns}}$ & $8.22 *$ & $0.03^{*}$ & $1.31^{* *}$ & $0.16^{* *}$ & $46967^{* *}$ & $0.43^{*}$ \\
\hline Error & 266 & 36.4 & 2.55 & 2.23 & 0.01 & 0.26 & 0.03 & 7527 & 0.10 \\
\hline
\end{tabular}

\section{Standard length}

There was no significant difference $(\mathrm{P}>.05)$ in the initial mean standard length across the three treatments nor in the weekly recordings across the five weeks (Figure 1). The overall mean initial standard length was $10.85 \pm .05 \mathrm{~cm}$, while it was $10.82 \pm .08 \mathrm{~cm}, \quad 10.82 \pm .09 \mathrm{~cm}$ and $10.90 \pm .09 \mathrm{~cm}$ for the 6,8 and 12-hourly regimen, respectively.

However, there was significant $(\mathrm{P}<.05)$ difference in the final standard length across the three treatments (Table 1) and the coefficient of determination of the model was 60.87 percent. The overall final standard length was $8.81 \pm .12 \mathrm{~cm}$, but the 6hourly regimen had the highest value of $9.21 \pm .19 \mathrm{~cm}$, which was statistically $(\mathrm{P}<.05)$ higher than $8.53 \pm .21 \mathrm{~cm}$ recorded in the 12-hourly regimen, but the $8.70 \pm .20 \mathrm{~cm}$ recorded in the 8 -hourly regimen was intermediate between the other two treatments and was not statistically $(\mathrm{P}>.05)$ different.

\section{Computed Indices}

Length weight relationship: Logarithmic transformation of the weight and length of the fish resulted in the regression equations presented in Table 2. It was observed that the growth coefficient (b) in the 6-hourly treatment has positive allometry $(b>3)$ while the other two treatment groups had negative allometry $(b<3)$.

\section{Condition Factor (K)}

This is a measure of the health of the fish, and feeding regimen exerted significant $(\mathrm{P}<.05)$ influence on this parameter (Table 1). Surprisingly, the 8-hourly treatment group had the highest values while the 12hourly group had the least (Table 3), which is an indication of improved wellness and health of the 8-hourly group compared to other treatment groups. The model for condition factor had the least coefficient of determination of all parameters studied which was 12.83 percent.

\section{Specific Growth Rate (SGR)}

Effect of feeding regimen was a highly significant $(\mathrm{P}<.01)$ source of variation in specific growth rate (Table 1) and the model explained 35.57 percent of variation in specific growth rate. Mean values from 6hourly regimen was significantly $(\mathrm{P}<.05)$ higher than values obtained in the 12-hourly treatment group, but the 8-hourly group was intermediate between the two extreme values (Table 3 ). 


\section{Influence of feeding regimen}
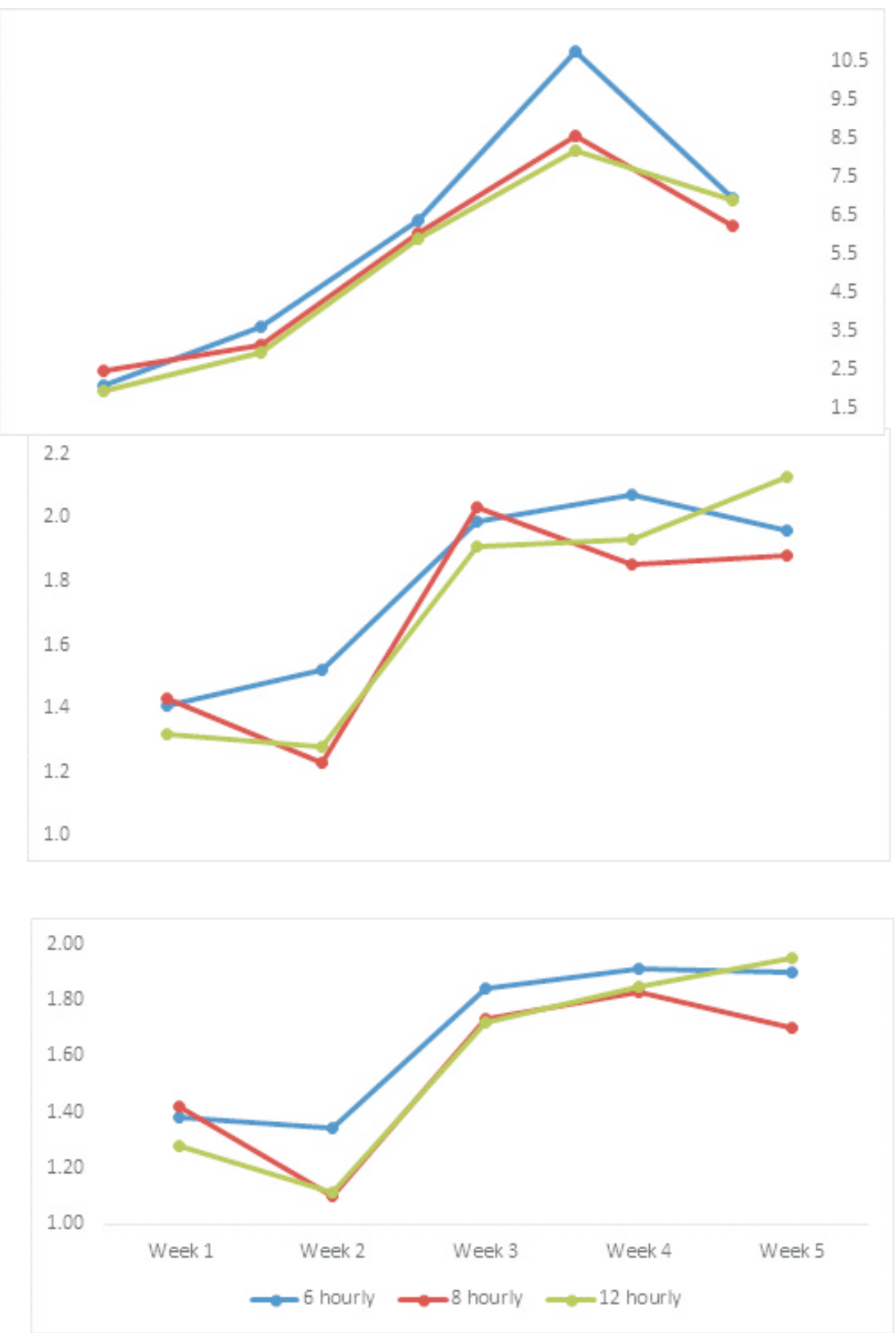

Figure 1: Weekly distribution of weight gain $(\mathrm{g})$, total length $(\mathrm{cm})$ and standard length $(\mathrm{cm})$ across the three different feeding regimens

It is worthy of note that the coefficient of determination for the three regression equations revealed that the 8-hourly treatment had a better fit of $79.3 \%$ while the 6 -hourly treatment had the lowest $\mathrm{R}^{2}$ value of $73.8 \%$ which is below the average of the three treatments. 
Abanikannda, Jimoh, Bakare, Shitta and Shopeyin

Table 2: Regression of Log Weight on Log Length across Treatments

\begin{tabular}{lllll}
\hline Treatments & $\mathbf{N}$ & $\mathbf{a}$ & $\mathbf{b}$ & $\mathbf{R}^{\mathbf{2}}$ \\
\hline 6-hourly & 90 & -2.62 & 3.10 & 73.8 \\
8-hourly & 90 & -2.27 & 2.85 & 79.3 \\
12-hourly & 90 & -2.37 & 2.91 & 77.9 \\
Combined & 270 & -2.39 & 2.93 & 77.0 \\
\hline \multicolumn{1}{c}{$\mathbf{R}^{2}=$ Coefficient of Determination } & &
\end{tabular}

Table 3: Growth Parameters of Clarias gariepinus

\begin{tabular}{lllllll}
\hline Treatments & N & SGR (\%) & AGR & RGR & MGR & CF \\
\hline 6-hourly & 90 & $4.37 \pm .06^{\mathrm{a}}$ & $0.85 \pm .04^{\mathrm{a}}$ & $437.5 \pm 10.7^{\mathrm{a}}$ & $3.56 \pm .03^{\mathrm{a}}$ & $0.48 \pm .01^{\mathrm{ab}}$ \\
8-hourly & 90 & $4.24 \pm .08^{\mathrm{ab}}$ & $0.80 \pm .04^{\mathrm{a}}$ & $418.0 \pm 12.8^{\mathrm{ab}}$ & $3.48 \pm .04^{\mathrm{ab}}$ & $0.50 \pm .01^{\mathrm{a}}$ \\
12-hourly & 90 & $4.14 \pm .06^{\mathrm{b}}$ & $0.77 \pm .04^{\mathrm{b}}$ & $393.2 \pm 10.8^{\mathrm{b}}$ & $3.43 \pm .04^{\mathrm{b}}$ & $0.47 \pm .01^{\mathrm{b}}$ \\
Combined & 270 & $4.25 \pm .04$ & $0.81 \pm .02$ & $416.3 \pm 6.71$ & $3.49 \pm .02$ & $0.48 \pm .01$ \\
\hline
\end{tabular}

\section{Absolute Growth Rate (AGR)}

The 6-hourly group had the highest value for absolute growth rate (Table 3) and influence of group was significant $(\mathrm{P}<.05)$ amongst the three treatments studied (Table 1). The coefficient of determination for the model was 79.19 percent due to initial weight and treatment.

\section{Relative Growth Rate (RGR)}

Effect of feeding regimen was a highly significant $(\mathrm{P}<.01)$ source of variation in RGR (Table 1), with the 6-hourly treatment recording the highest values and 12-hourly regimen had the least (Table 3 ). The 8 hourly treatment group had intermediate values between the two extreme values and was not statistically $(\mathrm{P}>.05)$ different from the other two values (Table 1). The model was able to explain 38.68 of variation in relative growth rate using only the initial weight and feeding regimen as sources of variation.

\section{Mean Growth Rate (MGR)}

The model explained 32.23 percent of variation in mean growth rate and feeding regimen was a significant $(\mathrm{P}<.05)$ source of variation in mean growth rate (Table 1). There was a 3.79 percent superiority of the 6-hourly group mean on the 12-hourly group, while the difference between the 8- hourly group and the other two treatments was marginal (Table 3 ).

\section{Discussion}

Initial Weight: There was similarity in the initial weight of the three groups because the random selection and assignment had averaged out the likely variation that could have inherently existed between the groups. Aside from the nearly equal mean values of initial weight between the groups, the variability within the three groups was very similar with coefficient of variation of $23.02,22.58$ and 22.66 percent respectively for the 6, 8 and 12-hourly treatment groups.

\section{Weekly Weight Gain}

The 8-hourly treatment group had the highest gain in week 1 which is almost 26 percent higher than gain recorded by the 12hourly treatment group and 17 percent higher than the 6-hourly group (Figure 1). In subsequent weekly weight gain recordings, the 6-hourly group consistently had the highest values for the remaining four weeks, albeit there was no difference in the $5^{\text {th }}$ week weight gain between the groups. The greatest difference in weekly weight gain between the highest and lowest mean was recorded in week $4(2.58 \mathrm{~g})$ between the 6-hourly group and the 12- 


\section{Influence of feeding regimen}

hourly group, while the least was in week 1 $(0.15 \mathrm{~g})$. This weekly difference in weight gain is in consonance with earlier reports (Ruhohen et al., 1998; Ibiyo et al., 2007; Aderolu et al., 2010; Marimuthu et al., 2010; Asuwaju et al., 2014 and Jamabo et al., 2015) who all worked on Clarias under similar conditions as this study.

The 6-hourly treatment that feeds four times daily had the best gains across the weeks but such values were not statistically different from the values obtained in the 8-hourly group that feeds only thrice. Although feeding at optimum frequency result in noticeable reduction in feeding cost as suggested by Davies et al., (2006), it must be borne in mind that the additional cost of labour for more frequent feeding must be taken into consideration before adoption of the method.

\section{Final Weight Gain}

At the end of the study, the 6-hourly group gained 10.45 percent more than the 12hourly group (Figure 2), but a meagre 5.86 percent more than the 8 -hourly group. It should be noted that while there was a huge statistical difference between the 6 and 12hourly groups, there was no significant difference between the 6 and 8-hourly groups which is in consonance with submission of Bascinar et al (2007) who worked on Black Sea Trout in Turkey, that feed consumption and growth generally increase with feeding frequency to a given limit.

The significant difference in weight gain recorded in this study is in close agreement with the reports of Asuwaju et al (2014) who also worked on Clarias gariepinus in their 49-day study.

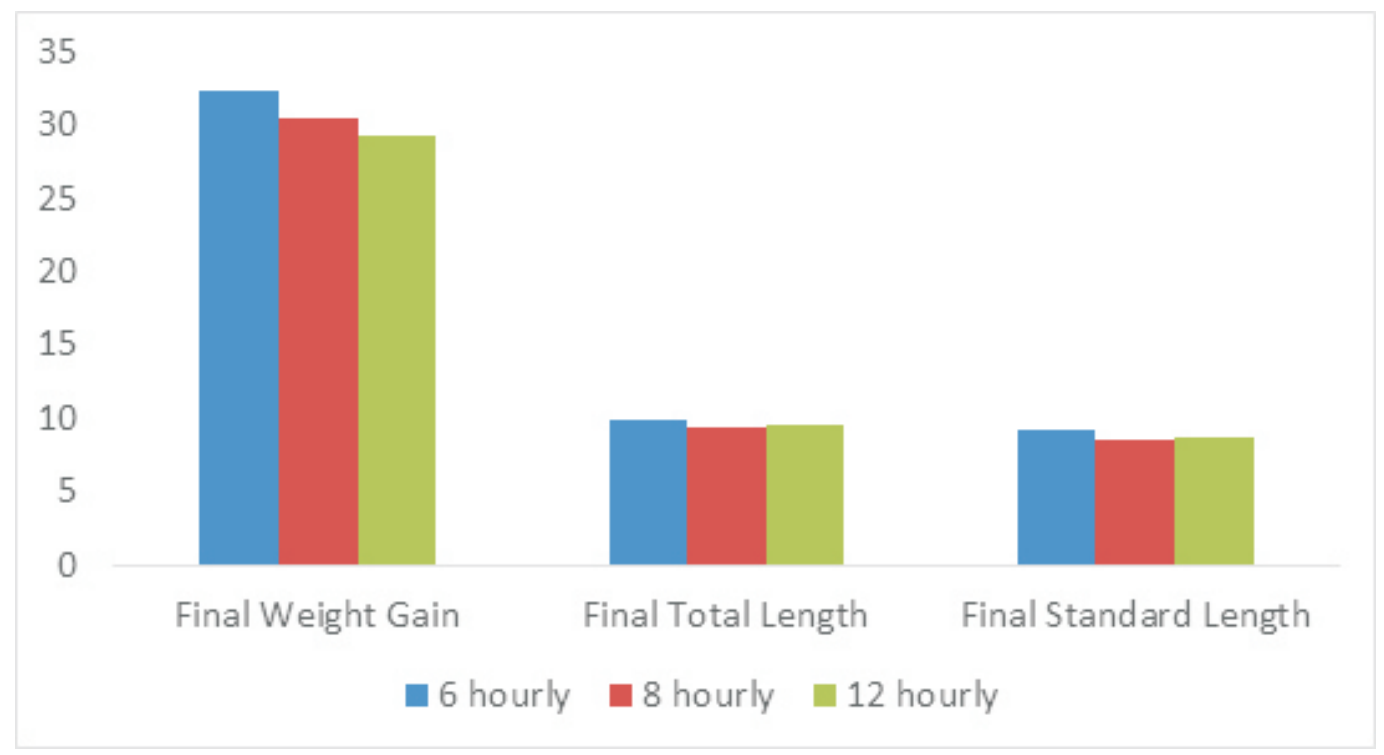

Figure 2: Histogram of final weight gain (g), final total length (cm) and final standard length $(\mathrm{cm})$ across the three different feeding regimen 


\section{Abanikannda, Jimoh, Bakare, Shitta and Shopeyin}

\section{Total Length}

Total length mean did not follow any consistent pattern throughout the study, and the effect of treatment group on total length at the end of the study which was not different between groups. This implies that despite the numerical differences in the total length, the within group difference is so large not to allow the between group difference significant.

\section{Standard Length}

Effect of treatment group on standard length followed a similar trend as that of total length all through the study except at the final standard length. The 6-hourly group had the highest final standard length (Figure 2) and it was 7.97 percent higher than the 8-hourly group which had the least. This may be attributed to higher increase in size and weight of this treatment group. The relationship between weight and standard length is direct and as such impact the standard length.

\section{Length-Weight Relationship}

The positive allometry of the 6-hourly group is indicative of the superiority of this group in terms of weight prediction based on length (Table 2). This implies that better responses are recorded on weight as a consequence of unit change in length of the fish in the 6-hourly group. However, the lower coefficient of determination of the model suggest that some other salient factors might have contributed to this observation. This observation supports the report of Panase and Mengumpham (2015) who worked on hybrid catfish in net cages and the difference in b-values may be due to differences in feeding regimen (Wooton, 1990).

\section{Condition Factor}

This is a measure of the wellness and health of the individual fish in a population (Stevenson and Woods, 2006), and the 8hourly group had the best value of 0.50 , while the least of 0.47 was recorded in the 12-hourly group. This difference among the three groups, supported earlier reports on the same specie (Panase and Mengumphan, 2015; Haruna et al, 2014; Ayoade, 2011 and Ekelemu, 2010). Although, Kasiri et al., (2015) reported that feeding frequency did not affect condition factor in the Angel Fish (Pterophyllum scalare) they studied in Iran.

\section{Absolute Growth Rate}

The difference in absolute growth rate is a reflection of the daily gain across the three treatment groups. However, the values decreased with decreasing number of times the fish were fed, with the highest values recorded in the 6-hourly and the least in the 12-hourly group. This indicate that whilst the daily gain was statistically different in itself, the large difference in the final weight is then attributable to the frequency of feeding and absolute growth rate of the fish.

\section{Specific Growth Rate}

The 5.56 percent increase in the specific growth rate of the 6-hourly group over the 12-hourly group is an indication of better growth and feed utilization in that treatment group. Although the 8-hourly group was intermediate between the other two (6 and 12 hourly) treatments. This observation is in line with various reports on effect of feeding frequency of Clarias on specific growth rate (Omodu et al., 2017; Okwuosa et al., 2016; Orire and Ozoadibe, 2015; Orire et al., 2013; Aderolu et al., 2010 and Amisah et al., 2009).

\section{Relative Growth Rate}

The 6-hourly treatment group had mean values that was 11.27 percent higher than the 12-hourly group that recorded the least (Table 3). The 8-hourly group was intermediate between the two extreme values of the other treatments. This corroborates the observations of Pantazis and Neofitou (2003), Emmanuel and Solomon (2013), Jamabo et al., (2015) and Omodu et al., (2017) in their respective 


\section{Influence of feeding regimen}

studies on growth characteristics of catfish. Mean Growth Rate (MGR)

The superiority of the 6-hourly group over the other two treatments is a reflection of better feed utilization within the group since feeding was well spaced, thereby reducing wastages. This is in alliance with the reports of Okwuosa et al. (2016), Liu and Liao (1999) and Robinson et al. (1995), who all worked on catfishes.

\section{Conclusions}

The study showed that differences in growth parameters of Clarias gariepinus is as a result of the different feeding regimen. It has established that when fish are fed correctly, growth rates are good and uniform across the population, FCR are low and pond water quality is optimized; In order to minimize wastages and inefficient feed utilization, optimum feeding regimes should be established and adopted in different stages of fish growth and development.

\section{References}

Abanikannda, O. T. F., Jimoh, A. A., Giwa, A. O. and Awosanya, L. A. 2019. Sexual dimorphism in body weight, morphometric measures and indices of African Catfish (Clarias gariepinus), Aquaculture 502: 148-152.

Adebayo, O. T. and Fagbenro, O.A. 2004. Induced ovulation and spawning of pond raised African giant catfish, Heterobranchus bidorsalis by exogenous hormones, Aquaculture, Vol. 242, Issues 1(4): 2004, Pages 229-236.

Aderolu, A. Z., Seriki, B. M., Apatira, A. L. and Ajaegbo, C. U. 2010. Effects of feeding frequency on growth, feed efficiency and economic viability of rearing African catfish (Clarias gariepinus, Burchell 1822) fingerlings and juveniles. African Journal of Food Science 4(5): 286 -290 .

Ali, M. Z., Hossain, M. A. and Mazid, M. A. 2005. Effect of mixed feeding schedules with varying dietary protein levels on the growth of sutchi catfish, Pangasius hypophthalmus (Sauvage) with silver carp, Hypophthalmichthys molitrix (Valenciennes) in ponds. Aquaculture Research, 36: 627 634.

Amisah, S., Oteng, M. A. and Ofori, J. K. 2009. Growth performance of the African catfish, Clarias gariepinus, fed varying inclusion levels of Leucaena leucocephala leaf meal. $J$. Appl. Sci. Environ. Manage. 13(1) $21-26$.

Asuwaju, F. P., Onyeche, V. O., Ogbuebunu, K. E., Moradun, H. F. and Robert, E. A. 2014. Effect of Feeding Frequency on Growth and Survival Rate of Clarias gariepinus Fingerlings Reared in Plastic Bowls. Journal of Fisheries and Aquatic Science, 9: 425-429.

Ayoade, A. A., 2011. Length-weight relationship and diet of African carp Labeo ogunensis (Boulenger, 1910) in Asejire Lake Southwestern Nigeria. J. Fish. Aquat. Sci., 6: 472-478.

Bagenal, T.B. 1978. Methods for assessment of fish production in freshwaters. IBP Handbook No. 3, Blackwell Scientific Publication, 3rd Edition, London, 300 pages.

Basçınar, N., Çakmak, E., Çavdar, Y. and Aksungur, N. 2007. The effect of feeding frequency on growth performance and feed conversion rate of Black sea trout (Salmo trutta labrax Pallas, 1811). Tur. J. 
Fisheries. Aqua. Sci., 7: 13-17.

Booth, M. A., Tucker, B. J., Allan, G. L. and Stewart Fielder, D. 2008. Effect of feeding regime and fish size on weight gain, feed intake and gastric evacuation in juvenile Australian snapper Pagrus auratus, Aquaculture 282, 1 (4): 104-110.

Brown, M. E. 1957. Experimental Studies on Growth. In: The Physiology of Fishes, Varley, M.E. (Ed.). Vol. 1, Academic Press, New York, USA., pp: 361-400.

Craig, S. 2002. Understanding fish nutrition, Feeds and feeding. Virginia Cooperative Extension, Virginia Tech. Virginia State University Publication 420:256. $\mathrm{W}$ e $\mathrm{b} \quad \mathrm{s}$ i $\mathrm{t}$ e : http://www.ext.vt.edu/pubs/fisheri es/ 420-256/420-256.html.

Davies, O. A., Inko-Tariah, M. B. and Amachree, D. 2006. Growth response and survival of Heterobranchus longifilis fingerlings fed at different feeding frequencies. Afr. J. Biotechnol., 5: 778-787.

Ekelemu, J. K. 2010. Differential growth patterns of Clarias gariepinus, Heterobranchus bidorsalis and hybrid Heteroclarias fed commercially prepared diets. Agric. Biol. J. N. Am., 1:658-661.

Emmanuel. C. A. and Solomon, R. J. 2013. The growth rate and survival of Clarias gariepinus fingerlings in Tap, Borehole and Stream Waters. Academia Arena 5(7): 1-17.

FAO. 2012. Fishstat Plus, Vers. 2.32. Rome, FAO. (available at www.fao.org/fishery/statistics/soft ware/fishstat/en

Fulton T. W. 1904. The rate of growth of ? shes. Twenty Second Annual Report, Part III. Fisheries Board of
Scotland, Edinburgh, pp. 141-241. George, F. O. A., Olaoye, O. J., Akande, O. P. and Oghobase, R. R., 2010. Determinants of aquaculture fish seed production and development in Ogun State, Nigeria. Journal of Sustainable Development in Africa. 12. 22-34.

Haruna, M. A., Muhd, I. U., Ahmad, M. K. and Umar, R., 2014. Evaluation of different feeding frequencies on growth performance and feed utilization of Clarias gariepinus (Burchell, 1822) fingerlings Bayero Journal of Pure and Applied Sciences 7(2): $142-144$.

Hecht, T. 2013. A review of on-farm feed management practices for North African catfish (Clarias gariepinus) in sub-Saharan Africa. In M.R. Hasan and M.B. New, eds. On-farm feeding and feed management in aquaculture. FAO Fisheries and Aquaculture Technical Paper No. 583. Rome, FAO.pp. 463-479.

Hopkins, K. D. 1992. Reporting Fish Growth: A Review of the Basics. Journal of the World Aquaculture Society. 23. 173-179.

Ibiyo, L. M. O., Atteh, J. O. Omotosho, J. S. and Madu, C. T. 2007. Vitamin C. (ascorbic acid) requirements of Heterobranchus longifilis fingerlings. African Journal of Biotechnology 6:1559-1567.

Isyagi, N., Atukunda, G., Aliguma, L., Ssebisubi, M., John, W., Kubiriza, G. and Mbulameri, E. 2009. Assessment of national aquaculture policies and programmes in Uganda. SARNISSA EC FP7 Project. Contract Number 213143, Stirling, United Kingdom, University of 
Stirling. $79 \mathrm{pp}$.

Jamabo, N. A., Fubara, R. I. and Dienye, H. E. 2015. Feeding Frequency on Growth and Feed Conversion of Clarias Gariepinus (Burchell, 1822) Fingerlings. International Journal of Fisheries and Aquatic Studies 3(1): 353-356.

Kasiri, M., Farahi, A. and Sudagar, M. 2011. Effects of Feeding Frequency on Growth Performance and Survival Rate of Angel Fish, Pterophyllum scalare (Perciformes: Cichlidae). Veterinary Research Forum, 2(2), 97-102.

Li, M. H., Bruce B. M. and Robinson, E. H. 2004. Effect of Daily Feed Intake on Feed Efficiency of Juvenile Channel Catfish, North American Journal of Aquaculture, 66:2, 100-104.

Liu, F. G. and Liao, C. I. 1999. Effect of feeding regime on the food consumption, growth and body composition in hybrid striped bass Morone saxitilis $\times M$. chrysops. Fish. Sci. 64: 513-519.

Marimuthu, K., Cheen, A. C., Muralikrishnan, S. and Kumar, D. 2010. Effect of different feeding frequency on the growth and survival of African Catfish (Clarias gariepinus) fingerlings. Advances in Environmental Biology 4(2):187-193.

Ndome, C. B., Ekwu, A. O. and Ateb, A. A. 2011. Effect of Feeding Frequency on Feed Consumption, Growth and Feed Conversion of Clarias gariepinus \% $\mathrm{x}$ Heterobranchus longifilis \& Hybrids, American-Eurasian Journal of Scientific Research 6 (1): 6-12.

Okwuosa, O. B., Nwachukwu, V. N.,
Agha, E. P. and Enyinnaya, C. I. 2016. The impact of feeding frequency on the growth and survival of Clarias gariepinus Fingerlings fed at different percentage body weight in four phases. International Journal of Fisheries and Aquatic Studies 4(5): 173-178.

Omodu, A. O., Solomon, R. J. and Wilfred-Ekprikpo, P.C. 2017. Length Weight Relationship of Clarias Garienpinus (Catfish) fed with Local Feeds. $N$ Y Sci. J. 10(5): 46-59.

Orire, A. M., Omotoyinbo, S. O. and Sadiku, S. O. E. 2013. The Growth and Body Composition of Clarias gariepinus Fingerlings Fed Combined Different Sources of Lipid. J. Aquac. Res. Development. 4: 182-186.

Orire, A. M. and Ozoadibe, T. N. 2015. Evaluation of growth performance and body composition of Clarias gariepinus fed graded level inclusion of Soybean waste. World Journal of Fisheries \& Aquaculture Sciences Research 1 (1): 1-9.

Panase, P. and Mengumphan, K. 2015. Growth Performance, LengthWeight Relationship and Condition Factor of Backcross and Reciprocal Hybrid Catfish Reared in Net Cages. International Journal of Zoological Research, 11: 57-64.

Pantazis, P. A. and Neofitou, C. N. 2003. Feeding frequency and feed intake in the African Catfish Clarias gariepinus (Burchell 1822). The Israeli Journal of Aquaculture Bamidgeh 55(3): 160-168.

Priestly, S. M., Stevenson, E. S. and Alexander, L. G. 2006. The 
influence of feeding frequency on growth and body composition of the common goldfish (Carassius auratus). JNutr. 136:1979-1981.

Ricker, W. E. 1975. Computation and interpretation of biological statistics of fish populations. Bull. Fish. Res. Board Can., 191: 1-382.

Robinson, E. H., Jackson, L. S., Li, M. H., Kingsbury, S. K. and Tucker, C. S. 1995. Effect of Time of feeding on growth of channel catfish. $J$. World Aquaculture Soc. 28: 320322.

Ruohonen, K., Vielma, J. and Grove, D. J. 1998. Effects of Feeding Frequency on Growth and Food Utilization of Rainbow Trout Oncorhynchus mykiss Fed LowFat Herring or dry Pellets. Aquaculture 165:111-121.

Schnaittacher, G., King, W. and Berlinsky, D. L. 2005. The effects of feeding frequency on growth of juvenile Atlantic halibut, Hippoglossus hippoglossus L. Aquaculture Research, 36: 370377.

Stevenson, R. D. and Woods, W. A. 2006. Condition indices for conservation: New uses for evolving tools, Integrative and Comparative Biology. 46: 1169-1190.
Tesch, F. W. 1968. Age and growth. In: Methods for assessment of Fish and production in fresh waters. W. E. Ricker (Ed.). Blackwell Scientific Publications, Oxford, pp. 93-123.

Varela, J. L., Ruiz-Jarabo, I., VargasChacoff, L., Arijo, S., LeónRubio, J. M., García-Millán, I., Martín del Río, M. P., Moriñigo, M. A. and Mancera, J. M., 2010. Dietary administration of probiotic Pdp11 promotes growth and improves stress tolerance to high stocking density in gilthead seabream Sparus auratus. Aquaculture, 309(1-4), 265-271.

Wootton, R. J. 1990. The Ecology of Teleost Fishes. $1^{\text {st }}$ Edition. Chapman and Hall, London, UK. Pp 404.

Zidni, I., Herawati, T. and Liviawaty, E. 2013. Pengaruh padat tebar terhadap pertumbuhan benih lele sangkuriang Clarias gariepinus dalam sistem akuaponik. Jurnal Perikanan Kelautan. 4: 315- 324.

Received: $12^{\text {th }}$ April, 2019

Accepted: 15 ${ }^{\text {th }}$ June, 2019 